\title{
FLOWERING, NECTAR PRODUCTION AND INSECTS VISITS IN TWO CULTIVARS OF CUCURBITA MAXIMA DUCH. FLOWERS
}

\author{
Marta Dmitruk \\ Departament of Botany, University of Life Sciences, Akademicka 15, 20-950 Lublin, Poland
e-mail: marta.dmitruk@up.lublin.pl
}

Received: 16.03 .2008

S u m m a r y

The study was conducted on experimental plots in the conditions of Lublin. In the years 1998-2000 flowering, nectar secretion and insect visitation of male and female flowers of two winter squash (Cucurbita maxima Duch.) cultivars: 'Ambar' and 'Amazonka', were studied. The plants flowered from July to October. The flower life span was within the range of 7-10 hours. Female flowers of cv. Ambar were marked by the most abundant nectar secretion $(129 \mathrm{mg})$. The nectar sugar content can be estimated as average $(25 \%-35 \%)$. Winter squash nectar contained $84 \%$ of sucrose as well as $8-9 \%$ of fructose and $7 \%-8 \%$ of glucose. Flowers of the studied taxa were frequently foraged by the honey bee $(66 \%-98 \%$ of total insects) and bumblebees $(1 \%-30 \%)$.

Key words: Cucurbita maxima Duch., cultivars Ambar and Amazonka, flowering, nectar, insects

\section{INTRODUCTION}

Plants from the Cucurbitaceae family have been long cultivated and used by man in many ways. They are introduced into cultivation more and more readily due to their dietetic fruit. They are also appreciated as melliferous plants. Their apicultural value is associated with the prolonged time of flowering and the supply of nectar over a long period of time (D e m i a n o w i c z, 1953; Maurizio and Grafl, 1969). Squash flowers produce the largest amount of nectar among plants grown in our climatic conditions. One female flower can produce $400 \mathrm{mg}$ of nectar (L i p i ń s k i, 1982; B a n a s z a k, 1987).

The aim of the study was to compare the abundance of flowering and the amount of nectar secreted by flowers of two winter squash cultivars. The total sugar concentration and content of sucrose, fructose and glucose in nectar were also determined. The intensity of visitation of both sex flowers by pollinating insects was observed.

\section{MATERIALS AND METHODS}

The study was conducted in the years 1998-2000 on experimental plots in Al. Warszawska street in Lublin $\left(51^{\circ} 14^{\prime} \mathrm{N}\right.$ and $\left.22^{\circ} 32^{\prime} \mathrm{E}\right)$, on loess-based grey-brown podzolic soil.

Winter squash (Cucurbita maxima Duch.) plants belonging to two cultivars: Ambar and Amazonka, were seeded after 15 May and observations were made throughout the whole period of flowering.

The observations covered the date and duration of flowering, average flower life span, abundance of flowering, including the proportion between the number of male and female flowers, number of insect visits and time of insect visitation in flowers on specified dates in the years 1999-2000. The number of insects was recorded between 5.00 and 17.00, and results were given at 0.5-hour intervals. Nectar production was investigated using the pipette method, sampling at a time the amount of nectar from the whole flower life span (D e m i a n o w i c z et al. 1960). The percentage nectar sugar content was determined using the Abbe refractometer. Based on the average weight of nectar sugars and abundance of flowering, sugar yield was calculated for the two studied taxa which was then translated into the so-called honey yield. In 2000, at the Puławy-based Division of Apiculture of the Institute of Pomology and Floriculture, the nectar sugar content was determined using gas chromatography in accordance with the harmonised methods of the European Honey Commission (B o g d a n o v et al. 1997).

\section{RESULTS}

\section{Duration of flowering}

Observations of flowering carried out in the years 1998-2000 demonstrated that, depending on the year and cultivar, the start of winter squash flowering fell on different decades of July, and even the first decade of 
August. The end of flowering was noted from the second decade of September till the first decade of October. The average duration of flowering for winter squash was from 72 days (cv. Amazonka) up to 80 days (cv. Ambar) (Tab. 1).

\section{Flower blooming and flower life span}

In their final development stage, swollen flower buds of winter squash changed their colour from light green to yellow. After the bud reached the size of at least $2 \mathrm{~cm}, 5.5$ days (female flowers) up to 10 days (male flowers) elapsed until the open flower stage (Figs 1,2).

Changes leading to flower opening in most of the investigated plants started between 2.30 and 3.00. At this time, anther dehiscence and pollen release in the bud were also observed. The flower bud loosening was associated with the appearance of small slits visible at $1 / 3$ height of the corolla length until the corolla petals took a position almost perpendicular to the flower axis. For both taxa, on the average, $1 / 2$ hour elapsed from the loosening of petals at the bud apex to corolla opening. The duration of the open flower stage and hours of corolla opening and closing differed, depending on flower sex, cultivar and weather conditions in the particular year and month. In 1999 male flowers opened 1/2 hour before female flowers, whereas in 1998 the opening of flowers of both sexes was almost simultaneous. Winter squash flowers opened between 4.30 and 6.30. The duration of the open flower stage from corolla opening until corolla closing for winter squash was from 7 up to 10.5 hours. Winter squash flowers closed between 13.00 and 17.00. The process of flower closing lasted about 1 hour (Fig. 4).

Abundance of flowering

Intensively smelling flowers of Cucurbita maxima Duch. cv. Ambar and cv. Amazonka have a five-lobed, radial, yellow corolla with rounded lobes and the corolla diameter of $10 \mathrm{~cm}$ (Fig. 3).

When investigating the abundance of flowering, changes in the proportion of the number of male to female flowers were found in different growing periods. Generally, the number of male flowers exceeded the number of female flowers (5-20 times). On the average, winter squash cv. Ambar produced twice more male flowers (162) than cv. Amazonka (77). But the average number of female flowers of both cultivars was similar (Ambar - 10, and Amazonka - 11). The percentage share of male flowers on the cv. Ambar plant was 94\% and of female flowers $6 \%$, whereas for cv. Ambar it was $88 \%$ and $12 \%$, respectively (Tab. 1 ).

\section{Nectar secretion}

Nectar secretion in flowers started soon after flower opening, that is, already in the first hour of anthesis.

The average weight of nectar calculated for 10 flowers indicates that female flowers of winter squash cv. Ambar were marked by the most abundant nectar production - $1289.7 \mathrm{mg}$ of nectar. Both winter squash cultivars are characterised by the production of a larger amount of nectar in female than in male flowers (Tab. 2 ). The higher three-year average of nectar sugar concentration was noted in the case of male $(34.91 \%)$ and female $(32.04 \%)$ flowers of winter squash cv. Ambar. Cv. Amazonka exhibited similar percentage nectar sugar content in female flowers $(32.23 \%)$ and a smaller one in male flowers $(24.86 \%)$. The amount of sugars in nectar secreted by flowers, that is, their sugar yield, is a measure of the abundance of plant nectar production. The three-year averages of sugar weight in nectar from 10 flowers were the highest in female flowers of winter squash cv. Ambar (393.3 mg). The lowest average values of nectar sugar weight were noted in male flowers of winter squash cv. Amazonka (133.8 mg) (Tab. 2). The studied taxa were characterised by a larger nectar sugar weight in female than in male flowers. Female flowers of both winter squash cultivars produced about twice more nectar sugar than male flowers. Honey yield of winter squash. cv. Ambar was over 2.5 times higher than in the case of cv. Amazonka (Tab. 2).

Winter squash was characterised by a high percentage content of sucrose in the investigated amount of nectar, $25.6-27.8 \%$, what made up a large percentage share of this sugar in total sugar content determined as $100 \%(83-84 \%)$. Monosaccharides were found in winter squash nectar in much smaller amounts, fructose in the range of $2.5-3.1 \%$ and glucose $2.4-2.5 \%$ (Tab. 3).

\section{Insect visitation}

Squash flowers are entomophilous. The main pollinators of the observed taxa were honey bees (Apis melifera) (66 - 98.5\%) and bumblebees (Bombus sp.) (1.3-30\%). Flies (Diptera), beetles (Cucumber beetles) and ants (Formicidae) also appeared in the flowers.

Bees started their flower visitation between 7.00 and 7.30. The peak time of mass appearance of bees was between 8.00 and 12.30. The largest number of visits in one flower was noted in winter squash cv. Amazonka (141.5). A larger number of bee visits in male than in female flowers was observed over their whole life span (Fig. 5).

\section{DISCUSSION}

The sequence of blooming of winter squash flowers of particular sexes is different, depending on the vegetation year. Many authors (Demianowicz, 1953; Li piński, 1982; F a j k ow s ka, 1985; D orofeev et al. 1990; Nepi and Pacini, 1993; M as i e row ska and $\mathrm{Wi}$ e $\mathrm{n}, 2000$ ) report that male flowers appear on the plant from 2 up to 8 days earlier than female flowers. The variation in these results can be explained by the correlation of the sex of flowers produ- 

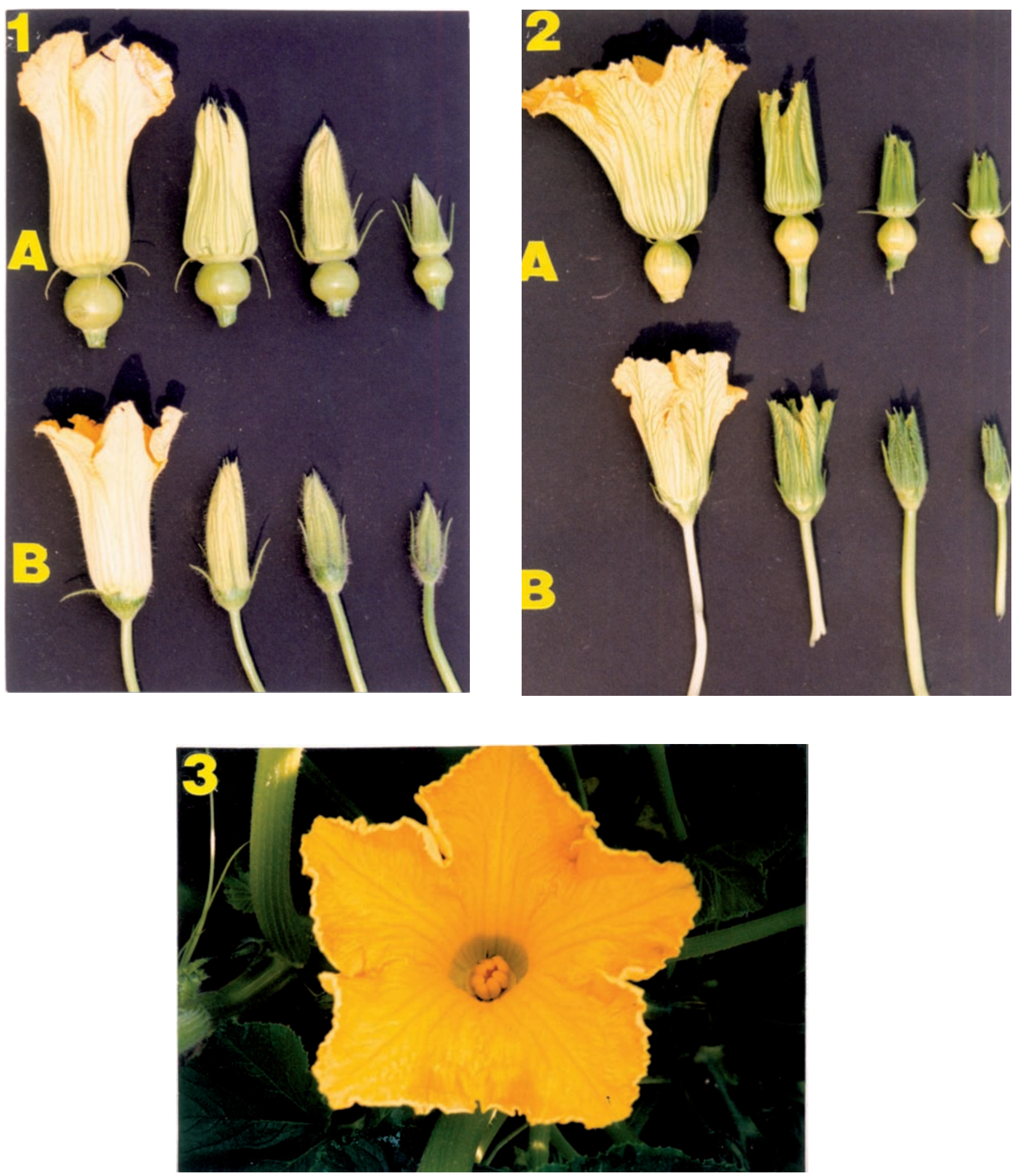

Fig. 1. Different development stages of winter squash cv. Ambar flowers: A - female flower, B - male flower.

Fig. 2. Different development stages of winter squash cv. Amazonka flowers: A - female flower, B - male flower. Fig. 3. Female flower of winter squash cv. Ambar. 


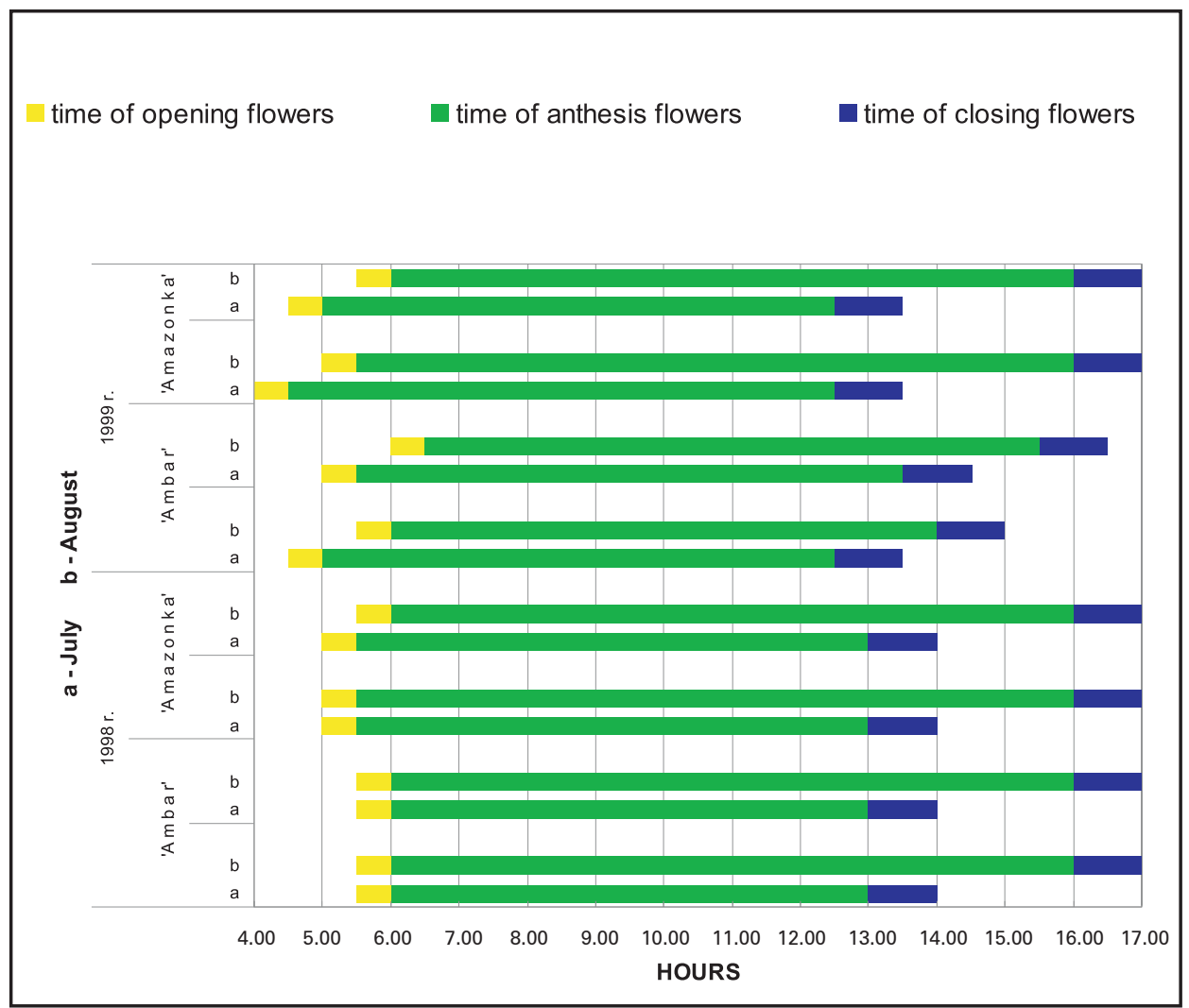

Fig. 4. Life span of male and female flowers of two cultivars of winter squash in 1998-1999 years.

ced with weather conditions, primarily temperature and light. $\mathrm{N}$ it s c h et al. (1952) recognise high temperature and long day to be factors favouring the production of staminate flowers, whereas low temperature and short day - the development of pistillate flowers.

It the present study, it was demonstrated that more male than female flowers developed on plants of the studied taxa throughout the whole period of flowering. The proportion of male to female flowers in winter squash cv. Ambar was 16.6, whereas in cv. Amazonka it was 7.2. The advantage in the number of male compared to female flowers was also noted by $\mathrm{F}$ a j k o w s k a (1985) and B attag lin i (1968) who observed 10 staminate flowers per one pistillate flower on a squash plant. Similar results were obtained by $\mathrm{Nepi}$ and $\mathrm{Pac}$ in i (1993) who found that 7.9 times more male than female flowers were produced in summer squash (Cucurbita pepo). They add that this proportion may slightly change during vegetation.

In the taxa investigated in my study, the average number of female flowers, produced by one plant over the whole growing period (winter squash cv. Ambar - 9.7; cv. Amazonka - 10.7) much exceeded the number given for summer squash by $\mathrm{Nepi}$ and $\mathrm{Pac}$ in i (1993), which was 4.5. In summer squash, M a si erow s k a and W i e n (2000) noted the number of female flowers within the range of $7.1-13.5$ in summer squash.
My observations show that flowers of both winter squash cultivars were characterised by a short life span which was about 9 hours. Depending on the species and weather conditions as well as the time of the growing period, flowers opened between 4.00 and 6.00 and closed between 10.00 and 17.00. Many authors (Mc Gregor, 1976; Lipiński, 1982; B anaszak, 1987; Dorofeev et al. 1990; Philippe, 1991; $\mathrm{Nepi}$ and Pacini, 1993; Nepi et al. 1996) confirm the short duration of the open flower stage in squash. Similar hours of flower opening were noted by: $\mathrm{Ne} \mathrm{p} \mathrm{i}$ et al. (1996) 5.00-6.00; M a s i e row s k a and W i e n (2000) 5.00, and slightly later hours by D o r o f e e v et al. (1990) $6.00-8.00$.

The opening of flowers of both sexes lasted about $1 / 2$ hour and closing about 1 hour. It is consistent with the description of the process of closing and opening of summer squash flowers contained in the paper by $\mathrm{N} \mathrm{e} \mathrm{p} \mathrm{i}$ and P a c in i (1993).

Maurizio and Grafl (1969) reported that winter squash flowers produced $201 \mathrm{mg}$ of nectar with the nectar sugar concentration at the level of $20 \%$. The study presented in the present paper shows smaller amounts of nectar secreted by winter squash flowers: $132.2 \mathrm{mg}$ (cv. Amazonka) - $181.0 \mathrm{mg}$ (cv. Ambar), but with higher sugar content of $24.9 \%-34.9 \%$. My study proves that higher nectar secretion takes place in fema- 
Table 1

Period and abundance of flowering two cultivars Cucurbita maxima.

\begin{tabular}{|c|c|c|c|c|c|c|}
\hline \multirow{2}{*}{ Cultivars } & \multirow{2}{*}{ Year } & \multirow{2}{*}{$\begin{array}{l}\text { Sex of } \\
\text { flower }\end{array}$} & \multirow{2}{*}{$\begin{array}{c}\text { Flowering } \\
\text { period }\end{array}$} & \multirow{2}{*}{$\begin{array}{c}\text { Numer of } \\
\text { flowers per } \\
\text { plant }\end{array}$} & \multicolumn{2}{|c|}{$\begin{array}{l}\text { Mean of numer } \\
\text { flowers per plant }\end{array}$} \\
\hline & & & & & $\hat{0}$ & q \\
\hline \multirow{6}{*}{ Ambar } & \multirow[b]{2}{*}{1998} & $\widehat{0}$ & $20.07-22.09$ & 210.6 & \multirow{6}{*}{161.7} & \multirow{6}{*}{9.7} \\
\hline & & q & $23.07-22.09$ & 13.4 & & \\
\hline & \multirow[b]{2}{*}{1999} & $\hat{\sigma}$ & $12.07-10.10$ & 100.4 & & \\
\hline & & 우 & $7.07-28.09$ & 4.8 & & \\
\hline & & $\widehat{0}$ & $14.07-27.09$ & 174.0 & & \\
\hline & 2000 & q & $14.07-23.09$ & 11.0 & & \\
\hline \multirow{6}{*}{ Amazonka } & & ๙ & $20.07-22.09$ & 78.3 & \multirow{6}{*}{76.8} & \multirow{6}{*}{10.7} \\
\hline & 1998 & 우 & $28.07-22.09$ & 15.0 & & \\
\hline & \multirow[b]{2}{*}{1999} & o & $7.07-13.09$ & 94.0 & & \\
\hline & & q & $2.07-27.08$ & 5.4 & & \\
\hline & \multirow[b]{2}{*}{2000} & $\widehat{0}$ & $11.07-25.09$ & 58.2 & & \\
\hline & & 우 & $13.08-30.09$ & 11.8 & & \\
\hline
\end{tabular}

Table 2

Characteristic of nectar producted in two cultivar Cucurbita maxima flowers.

\begin{tabular}{|c|c|c|c|c|c|}
\hline \multirow{4}{*}{ Examined parameters } & \multirow{4}{*}{ Year } & \multicolumn{4}{|c|}{ Cultivars } \\
\hline & & \multicolumn{2}{|c|}{ Ambar } & \multicolumn{2}{|c|}{ Amazonka } \\
\hline & & \multicolumn{4}{|c|}{ Sex of flower } \\
\hline & & $\sigma^{\lambda}$ & q & $\hat{0}$ & q \\
\hline \multirow{4}{*}{ Nectar amout per 10 flowers (mg) } & 1998 & 538.3 & 1208.8 & 160.0 & 383.0 \\
\hline & 1999 & 269.4 & 1176.7 & 763.3 & 1088.3 \\
\hline & 2000 & 748.6 & 1484.5 & 630.0 & 878.7 \\
\hline & Mean & 518.8 & 1289.7 & 518.4 & 783.3 \\
\hline Sugar content in nectar $(\%)$ & Mean & 34.91 & 32.04 & 24.86 & 32.23 \\
\hline Total sugar wieght in nectar per 10 flowers $(\mathrm{mg})$ & Mean & 182.8 & 393.3 & 133.8 & 254.4 \\
\hline \multicolumn{2}{|l|}{ Bee honey productivity per 1 plant $(\mathrm{g})$} & \multicolumn{2}{|c|}{4.17} & \multicolumn{2}{|c|}{1.62} \\
\hline
\end{tabular}


Table 3

Sugars content in Cucurbita maxima cv. Ambar nectars.

\begin{tabular}{|c|c|c|c|c|c|c|c|c|}
\hline & \multicolumn{8}{|c|}{ Sex of flower } \\
\hline & 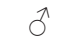 & 우 & $\sigma^{\pi}$ & 우 & $\sigma^{\pi}$ & q & $\sigma^{\pi}$ & q \\
\hline & \multicolumn{2}{|c|}{ Fructose $(F)$} & \multicolumn{2}{|c|}{ Glucose (G) } & \multicolumn{2}{|c|}{ Saccharose (S) } & \multicolumn{2}{|c|}{$\mathrm{S}:(\mathrm{F}+\mathrm{G})$} \\
\hline $\begin{array}{l}\text { Sugars content in } \\
\text { nectar sample (\%) }\end{array}$ & 2.52 & 3.14 & 2.40 & 2.54 & 25.58 & 27.85 & \multirow{2}{*}{$5.2: 1$} & \multirow{2}{*}{$4.9: 1$} \\
\hline $\begin{array}{l}\text { Sugars content in total } \\
\text { sugar weight }(\%)\end{array}$ & 8.26 & 9.09 & 7.87 & 7.47 & 83.81 & 83.44 & & \\
\hline
\end{tabular}

le flowers. F a h n (1949) and N e pi et al. (1996) also claim that pistillate flowers secret more nectar than staminate flowers.

However, in the present study female flowers of winter squash cv. Amazonka produced nectar with a higher sugar concentration than male flowers. But $\mathrm{K}$ a zi e va and S e i b ova (1965) report that pistillate flowers secret more nectar with a higher percentage sugar content.

Demianowicz (1953) reports that squash nectar contains the largest amount of sucrose. According to Z a u ralov and Pavlinova (1975) squash nectar is composed in $85 \%$ of sucrose, $6 \%$ glucose, $5 \%$ fructose and 3\% oligosaccharides. Qualitative and quantitative analysis of nectar of two winter squash cultivars presented in the present study showed a similar percentage content of sucrose $(83 \%-84 \%)$ and much larger amounts of glucose $(8 \%)$ and fructose $(9 \%)$. But no presence of oligosaccharides was found.

Winter squash flowers were mainly visited by bees and bumblebees, to a smaller extent by flies, beetles as well as ants. Bees accounted for $66 \%-98 \%$ of total insects. Numerous authors claim that the $\mathrm{Cu}-$ curbitaceae are visited and pollinated primarily by bees (Verdieva and Ismailova, 1960; Wolfenbarger, 1962). Banaszak (1987) reports that in the process of pollination of the Cucurbitaceae, apart from the honey bee, the large earth bumblebee and small garden bumblebee may be of some significance. Within America, squash flowers are visited by the honey bee, however, wild bees perform the main role in pollination and fruit set. Wild bee species belonging to Peponapsis and Xenoglossa collect eagerly not only nectar but also pollen of the Cucurbitaceae (M a ri zi o and Grafl, 1969; Free, 1970; Will is and Kevan, 1995).
My observations demonstrate that bees started foraging soon after the complete opening of winter squash flowers: $7.00-7.30$. Other authors give different hours of visitation of Cucurbitaceae flowers by bees. L i p ińs ki (1982) also states that bees start visitation of flowers after their opening. S a ndule a c (1959) noticed that squash flowers were pollinated by insects between 6.00 and 12.00. According to A tw a 1 (1970) insect visits took place between 7.00 and 10.30.

In the conditions of Lublin, the peak time of mass appearance of bees was between 8.00 and 12.30. S a n $\mathrm{du}$ l e a c (1959) gives a shorter time range: 8.00-9.00, relevant to three species: Cucurbita maxima, C. pepo and C. moschata. Nepi et al. (1996) demonstrated that the maximum frequency of insect visits in summer squash flowers also lasted an hour, but it started as early as 7.00. The presented time differences are undoubtedly associated with different climatic conditions relating to the observations made.

The observations of the present paper's author showed that, in the case of the winter squash cultivars studied, a larger number of bee visits related to male flowers, 16.1 - 141.5 (on the average, 65.3), than female flowers, $14.4-82.9$ (on the average, 49.2). The observations were carried out throughout the whole flower life span. Verdieva and Is mailova (1960) confirm that honey bees are more prone to visit better visible male flowers growing on long stalks. But S a n d u l e a c (1959) observed in winter squash 22.8 visits in the female flower and 16.1 in the male flower between 8.00 and 9.00, which was the peak time of bee foraging. 


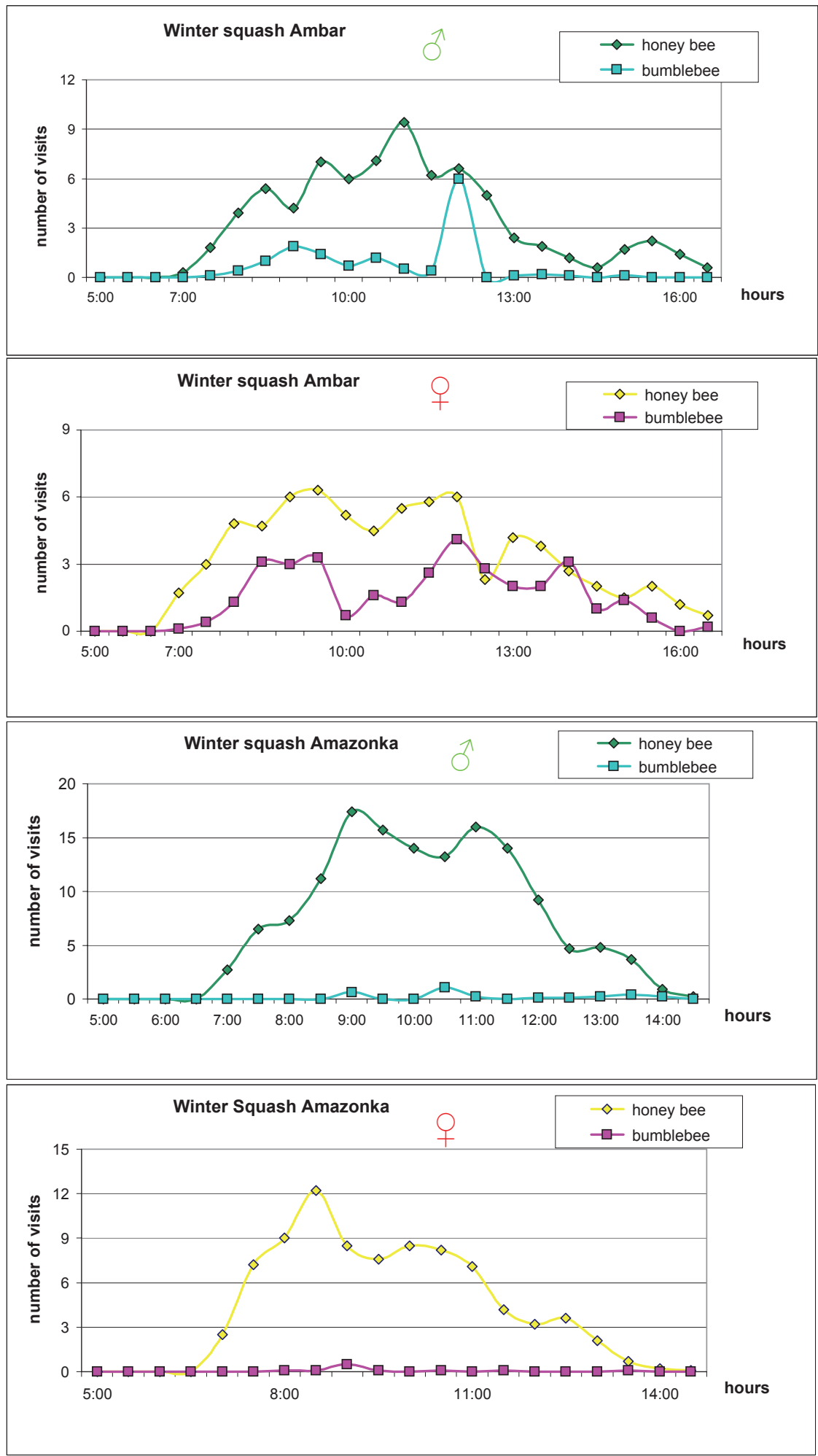

Fig. 5. Register of honey bee and bumblebee in winter squash flowers (mean for years 1999-2000). 


\section{CONCLUSIONS}

1. Winter squash cv. Ambar is characterised by a higher proportion of male to female flowers (16.6) than cv. Amazonka (7.2).

2. The study of flowers of both winter squash cultivars shows that female flowers of cv. Ambar are marked by the most abundant nectar secretion (129 mg).

3 . The nectar sugar content in winter squash can be estimated as average $(24.9 \%-34.9 \%)$. Squash nectar contains 5 times more sucrose $(84 \%)$ than fructose and glucose taken together (F: 8.3\%-9.1; G: 7.5-7.9\%).

4. Winter squash flowers are mainly visited by bees (65.8\%-98.5\%). A larger number of bee visits was observed in male (65.3) than in female flowers (49.2).

\section{REFERENCES}

Atwal A. S., 1970. Biology, ecology and utilization of insectes other than honey bees in the pollination of crops. Final Res. Rpt. (1965-70) Ludhiana, Punjab agric. Univ.

Banaszak J., 1987. Pszczoły i zapylanie roślin. PWRiL, Poznań.

Battaglini M. B., 1968. Importanza delle api nella fruittificazione di Cucurbita pepo L. / The importance of honeybees for fertilizing Cucurbita pepo L. L' Apicoltore d' Italia, 1: 3-6.

Bogdanov S., Martin P., Lüllman C., 1997. Harmonised methods of the European Honey Commision. Determination of sugar by GC. Apidologie, Extra issue: 45-47.

Demianowicz Z.,1953. Rośliny miododajne. PWRiL, Warszawa.

Demianowicz Z., Hłyń M., Jabłoński B., Maksymiuk I., Podgórska J., Ruszkowska B., Szlanowska K., Zimna J., 1960. Wydajność miodowa ważniejszych roślin miododajnych $\mathrm{w}$ warunkach Polski. / The honey yield of main plants in polnish conditions. Cz. I. Pszczeln. Zesz. Nauk. 4 (2): 87-103.

Dorofeev V. F., Laptev J. P., Čekalin N. M., 1990. Cvietenie opylenie i gibridizacija rastenij. „Agropromizdat” Moskva: 115-117.

Fahn A., 1949. Studies in the ecology of nectar secretion. Palest. J. Bot. Jerus. Ser. 4: 207-224.

Fajkowska H., 1985. Warzywa o największych owocach. PWRiL, Warszawa.

Free J. B., 1970. Insect Pollination of Crops. Academie Press. London i New York: 297-312.

Kaziev T. I., Seibova S. S., 1965. Nektaroproduktivnost' cvetkov predstavitelej tykvennyh v ustalovijah Azerbajdžana. XX Jubilejnyj Meždynarodnyj Kongress po Pčelovodstvu Izdatel'stvo, Moskva: 145-149.

Lipiński M., 1982. Pożytki pszczele, zapylanie i miododajność roślin. PWRiL, Warszawa.

Masierowska M. L., Wien H. C., 2000. Blütezeit, Bestäubung und Fruchtansatz bei zwei Kürbisabarten (Cucurbita pepo L.) unter Feldbedingungen. / Flowering period, pollination and fruit setting two cultivars of squash $(\mathrm{Cu}$ - curbita pepo L.) in the field conditions. Apiacta, 35 (3): 97-105.

Maurizio A., Grafl I., 1969. Das Trachtpflanzenbuch. Nectar und Pollen die wichtigsten Nahrungsquellen der Honigbiene. Band 4. Ehernwirth Verlag München.

Mc Gregor S. E., 1976. Insect Pollination of Cultivated Crop Plants. Agricultural Research Service US Departament of Agricultura. Washington S.C.

Nepi M., Pacini E., 1993. Pollination, Pollen Viability and Pistil Receptivity in Cucurbita pepo. Ann. Bot. 72: 527-536.

Nepi M., Pacini E., Wilemse M. T. M., 1996. Nectary biology of Cucurbita pepo: ecophysiological aspects. Acta Bot. Need, 45 (1): 41-54.

Nitsch J. P., Kurtz E.B., Jr., Liverman J. L., Went F. W., 1952. The development of sex expression in cucurbits flowers. Amer. J. Bot. 39: 32-43.

Philippe J. M., 1991. La Pollinisation Par Les Abeilles. Chapitre VI. Pollinisation Par Les Abilles des Cultures De Cucurbitacées. Edisud La Calade: 131-139.

Sanduleac E., 1959. Date despre polenizarea entomofilă si selectia Cucurbitaceelor. Lucrări Stiintifice. / Data on the entomophilous pollination and the selection of Cucurbitaceae. Lucr. Siint. Stat Cent. Seri Apic. 1: 129-132. 1: 129-132.

Verdieva M. G., Ismailova M. K., 1960. Vlijanie pčeloopylenija na povyšenie urožajnosti kormovoj tykvy. Pčelovodstvo, 37 (9): 40-41.

Wills D. S., Kevan P. G., 1995. Foraging dynamics of Peponapis pruinosa (Hymenoptera: Anthophoridae) on pumpkin (Cucurbita pepo) in southern Ontario. Can. Entomol. 127 (2): 167-175.

Wolfenbarger D. O., 1962. Honey-bees increase squash Yields. Res. Rep. Fla. Agric. Exp. Stn. 7 (1): 15-19.

Zauralov O. A, Pavlinova O. A., 1975. Transport i prevrascenie saharov v nektarnkah v svjazi s sekretnoj funkciej. Fizjologia Rast. 22 (3): 500-507.

\section{Kwitnienie, nektarowanie i oblot przez owady zapylające kwiatów dwóch odmian Cucurbita maxima Duch.}

\section{Streszczenie}

Badania przeprowadzono na poletkach doświadczalnych w warunkach Lublina. W latach 1998-2000 badano kwitnienie, nektarowanie i oblot przez owady kwiatów męskich i żeńskich dwóch odmian dyni olbrzymiej (Cucurbita maxima Duch.): 'Ambar' i 'Amazonka’. Rośliny kwitły od lipca do października. Długość życia kwiatu mieściła się w granicach 7-10 h. Najobfitszym wydzielaniem nektaru odznaczały kwiaty żeńskie odmiany Ambar (129 mg). Zawartość cukrów w nektarze można ocenić jako średnią (25\%-35\%). Nektar dyni olbrzymiej zawierał $84 \%$ sacharozy oraz fruktozy $8-9 \%$ i glukozy 7\%-8\%. Kwiaty badanych taksonów były chętnie oblatywane przez pszczołę miodną (66\%-98\% ogółu owadów) i trzmiele (1\%-30\%). 